\title{
PROBLEMS OF ADAPTATION OF A MAN TO THE CONDI- TIONS OF INFORMATION SOCIETY
}

\author{
Oleg Gennadievich Danilyan, Alexander Petrovich Dzeban, Yury \\ Yurievich Kalinovsky, Svetlana Borisovna Zhdanenko, Eduard Ana- \\ tolievich Kalnytskyi \\ Yaroslav Mudryi National Law University, Kharkiv, Ukraine
}

\begin{abstract}
The authors ascertain the main features of adaptation of a man to the conditions of the information society. There was applied the whole complex of philosophical, general scientific and specific methods inherent in philosophical research in their interconnection and complementarity. The methodology of the research is based on the principles of systemic and structural-functional analysis. As a result of the study, it was ascertained that a man as the highest social value accumulates and fixes in the main forms of his life the interconnection of material and spiritual, which reflects in an integral form life as the objective reality, where his interconnected interests, moral values, ideals, his culture, religious preference and subjective understanding of the meaning of life are revealed. The spreading of information technology is accompanied by the virtualization of all spheres of human life. The main social problems of adaptation of a person to the changing conditions of the information society that are proposed to consider are as follows: the problem of linguistic communication, which forms the core of informatization, and the problem of information security of an individual. It is substantiated that new paradigms form new perceptions by a person of his/her place in relation to the information environment and, accordingly, a new awareness of oneself and his/her own rights and freedoms. Specificity of the modern information environment leads to the correction of existing natural and social mechanisms of a person's adaptation and the development of new ones. Information technologies, having become the core of the modern civilization, change not only the quality and content of the life of a modern human, they threaten to transform the very way of his/her existence in the world. The transition to the information society can have unpredictable consequences. Therefore, the problems of formation of information society, the development of adequate to the objective reality methods and means of its life are the collective concern of all mankind.
\end{abstract}

\section{Keywords}

information society, adaptation, virtualization, information technology 


\section{Introduction}

Information society as a new type of society has a number of peculiarities in comparison with the previous types of societies. There is a sharp increase in the number of information flows and technical means, which not only ensures the circulation of information in society, but also provides the viability of the information society, identifies new problems and difficulties in social communication and in social interaction in general. There are processes of integration in various spheres of human activity that cause the process of globalization. There is a unique global communication system that provides humanity with the large volumes of accessible information. As a result, there are new forms of communication caused by the development of the global communications system. The processes of social communication, which became possible due to the virtualization of modern society, have become an important condition for the functioning of an individual in the modern information environment. Changes in the field of production, in the cultural environment, in the linguistic environment cause the change in the models of human behavior.

Accordingly, in the process of the dynamics of the information society social relations are changing, where tendencies towards concentration, bureaucratization and monopolization in the field of mass-information processes become characteristic. This forces a new look at some changes in the structure of the social system. The transfer of processes of physical social interaction into the simulation environment actualizes the correction of the view of the problem of human integration.

\section{Methods}

In this study, general scientific, philosophical and specific methods logically interconnected and mutually complementary are applied in a complex way. The methodology of the study is based on the principles of systemic and structural-functional analysis.

Thus, the dialectical method allowed to trace the cause-and-effect connection between the development of the information society and the problems of adaptation of a man to the conditions of modern social environment. The method of systemic analysis contributed to the complex and comprehensive disclosure of the factors of the information and communication and social nature, which affect the peculiarities of adaptation and selfrealization of an individual in the information society.

In turn, using the comparative method, the differences between the "physical" and "virtual" realities were identified and disclosed. The application of this method made it possible to conclude that virtuality is total and boundless; it covers a growing number of spheres of social life: "virtual economy", "virtual politics", "virtual love", "virtual theatre", etc. A logical complement to the comparative method in our study is the method of alternatives, which allowed to compare the various concepts of the information society and to identify the opposite points of view on the nature of human adaptation in it.

The scientific potential of the hermeneutic method became the basis for the disclosure of the essential features of such concepts as "virtual world", "information man". It is worth noting that for a comprehensive understanding of the concept of "information man" it is necessary to combine physical, psychological and social characteristics, which contributes to a deeper understanding of the adaptive practices of an individual in the modern multidimensional environment. The hermeneutic method in our scientific research was presented in conjunction with the methodological tools of postmodern philosophy.

\section{Problems of adaptation of a man to} the conditions of the information society in modern scientific literature

The results of the analysis of scientific sources indicate that the problems of the information society and the existence of a man in it are quite popular in the latest scientific discourse, as in the foreign (V. Bures, M.Coeckelbergh, M.-G.Arevalo Tapia, R.D.Ramos Grijalva, H. Schandle, etc.) /1/, /2/, $/ 3 /, / 4 /$, and in the domestic one (N. Bohdanova, V.Voronkova, O.Drozdovska, O.Kyvliuk, 
A.Mihalchuk, T.Tiurina, and others.) /5/, /6/, $/ 7 /, / 8 /, / 9 /$.

In particular, V. Bourres explores how modern information society influences human decision-making, what difficulties arise in the subject of decision-making in the new conditions. The work of this researcher identifies twelve decision-making factors due to the specifics of the information society. The thesis is based on the fact that the growing complexity of the information flows is an inevitable feature of the information society /1/.

In turn, M.Coeckelbergh, analyzes the peculiarities of social and political influence on the formation of evaluation of new technologies and their versatile manifestations in society. In the course of studying this problem, he unfolds a polemic over so-called "individualistic approaches" to understanding "good society" and recommends the scientists to use the resources of political philosophy more to solve the problem of understanding and evaluating technologies as a social phenomenon $/ \mathbf{2} /$.

A number of foreign researchers (R.D.Ramos Grijalva, M.G. Arevalo Tapia) in the thorough scientific work study the prevalence of the society of knowledge and information society under the influence of information and communication technologies as structural elements of social system. By revealing the essential features of the society of knowledge and the information society, the scientists analyze such concepts and areas of knowledge as cybernetics, technological platform, digital division, globalization, identity, etc. The conclusions made by the above-mentioned experts are aimed at actualizing the problem of the formation of the very society of knowledge, and not the information society $/ \mathbf{3} /$.

In H. Schandle's opinion, scientists need to pay more attention to the interaction of natural and social systems, which will ensure a better adaptation of a man in the world. In his view, we can not consider natural, cultural and social systems separately. Only an integrated approach to this problem is a guarantee of survival of the mankind /4/.

Ukrainian researchers also pay close attention to the problem of human adaptation to the fast-moving conditions of the information society. Thus, N. Bohdanova in the scientific work "The problem of self-realization of a person in the modern information society" interprets self-realization in the narrow sense as a career growth, success in business, gaining material well-being and in the broad sense as transforming oneself, finding one's own authenticity, changing life-practical orientations $/ 5 /$.

Instead, V. Voronkova and O. Kyvliuk, present the concept of a "smart society" as a new model of the information society. They analyzed the international experience of creating and developing a "smart society" and determined the dimensions of the axiological field of this type of society which is based on the axiological matrix of information and knowledge. The main idea of their reflections is to prove that the information society is evolving towards a "smart society" and to clarify the possibilities of creating such a society in Ukraine /6/.

According to O. Drozdovska, one of the important issues of the development of the information society in Ukraine as an environment of social adaptation is the protection of the information space of our country. To protect the Ukrainian information space, the following priority steps are needed: the development of the expert environment, state support for scientific developments in the field of information technologies, information policy and information security, in particular, promotion of media research and monitoring of the information space; creation of a new communication strategy of the power, mandatory components of which should be communication with the population, non-conflict communication within the authorities; communication with the outside world; introduction of the media literacy system in schools and universities; the transition from the prohibition policy to the policy of stimulating socially useful activity in the media sphere $/ 7 /$.

Continuing the above-mentioned reflections, A. Mykhalchuk notes that media communication in the information society is gradually changing the habitual communication, transforming the processes of thinking of a man in the direction from the real to the virtual. The real dimension is a sphere of nonlinear scientific knowledge, and the virtual one is a 
projection of a new digital reality, and not abstract, but integrating-technological thinking dominates in it $/ \mathbf{8} /$.

Accordingly, the development of the information society generates a number of anthropological and axiological problems in the adaptation practices of the present. In particular, T. Tiurina, in the light of V.I. Vernadskyi's concept of noosphere and the modern information and energy paradigm, considers a man as the microcosm and macrocosm at the same time, the cosmoplanetary phenomenon, a complex integral information and energy system, which is in the stable information and energy interconnections, interaction and mutual influence with the surrounding space. The researcher proves the evolutionary role of spirituality of a man in the process of harmonizing its informational and energy relations with the world, revealing at the same time the essence of the concept of "lack of spirituality", its content, forms of manifestation, involutional role as a destructive factor $/ \mathbf{9} /$.

Consequently, the study of this problem allows us to state that, despite the rather wide theoretical base of the phenomena under study, precisely the problems of integration (adaptation) of a man into the information continuum of the modern social environment need some clarifications, taking into account new information and technological processes.

The purpose of the article is an attempt to comprehend the main features of adaptation of a person to the conditions of the information society.

\section{The phenomenon of virtualization} of the living space of a man and society

Modern society should be seen as a communication system, where information and ideas are constantly exchanged, and where every member of society has the right to access information, to defend his or her own position. A person is one of the links that unites the entire social system. At the same time, he or she acts as the subject and the object of activity, social interests, needs and spiritual and moral values, ideals, beliefs and aspirations. Moral values directly related to the information sphere, significantly affect the nature of a person's activity and form the whole system of his/her individual and social relations. It is a person as the highest social value that accumulates in the main forms of his or her life the interconnection of the material and spiritual. Life as the objective reality is reflected in an integral form, in which internally interdependent interests, moral values, ideals of a person, his or her culture, religious preference and subjective understanding of the meaning of life are manifested. Society becomes the universal material and spiritual sphere in which an individual realizes oneself holistically. On the other hand, along with the socio-economic and political transformations of the information society, there is a process of reassessment of spiritual values, the formation of fundamentally new principles of morality. All this complicates the formation of a personality in the current information conditions.

The most important and most responsible aspect of adaptation of social system to the new forms of life in the information society and the formation of socio-cultural principles of relationship between the state and society in it is the development of the market of information services. It is formed, on the one hand, due to the emergence and the development of the needs of the state, corporate structures, individuals and institutions, i.e. clients, in the new types and kinds of information services, and, on the other hand, due to the development of specific types of informational commercial activities that have an independent social significance (advertising, marketing, etc.). Therefore, the cumulative social activity of the information society develops due to the identification of socially and culturally significant areas of information activity and the expansion of areas of its application. This largely transforms the nature, forms and types of socio-cultural interactions. This aspect of the development of the system of activities appears to be one of the most topical for the development of the information society, in which the social status, level of education and wealth depends on the quality and reliability of information and communication interactions, in which a person is included as the subject and as the object of information activity. The spreading of information technology both in the field of production and in the humanitarian sphere has caused a whole range of special- 
Oleg Gennadievich Danilyan, Alexander Petrovich Dzeban, Yury Yurievich Kalinovsky, Svetlana Borisovna Zhdanenko, Eduard Anatolievich Kalnytskyi: PROBLEMS OF ADAPTATION OF A MAN TO THE CONDITIONS OF INFORMATION SOCIETY

Media, Culture and Public Relations, 10, 2019, 1, 30-41

ly oriented services for the processing and use of information and communication means. They, in turn, determine the forms of transformation of the social environment in order to create conditions for the functioning of the information society.

The spreading of information technologies is accompanied by the virtualization of all spheres of human life, transforming from a simple technology into an informational and communicative environment. To date, the expansion of its influence is in two main interrelated directions: an increase in the influence of virtuality on the real world and the virtualization of reality itself. At the same time there is a gain of virtual status in all spheres of the human world and socio-cultural reality. Technical means and information techniques of the organization of virtual reality can radically change the nature and meaning of life as of one person, and a society as a whole. Consequently, awareness and assessment of social boundaries, as well as socio-cultural priorities of informatization, allows actualizing exactly those aspects of technologies that are aimed at the development of human life activities in various fields of production, science, art, education, trade, service industries.

The scale of penetration of virtual reality into social life gives the reason to speak about the "virtualization" of society, which changes the way people live. Virtuality is total and boundless, it covers a growing number of spheres of social life: "the virtual world", "virtual economy", "virtual politics", "virtual love", "virtual theatre". The constant acceleration of the virtualization of society and a man, caused by an increase in "the pictures of the world" and the virtualization of reality becomes obvious. This allows speaking about the continuous increase of realities, the multiplicity of which became the main motto of the present. In virtual reality, spatial and temporal delineations gradually disappear, interstate borders are erased, new values, models of behavior, worldlook stereotypes are propagated. The phenomenon of virtualization of the living space of a man and society characterizes a fundamentally new type of symbolic existence of a man, society, culture $/ \mathbf{1 0} /$.
4. The features of existence of a man in the information society

Virtualization of human life leads to the loss by a person the reasons for his or her existence, to the destruction of a truly human in a person, to the negative changes in his nature and the spiritual world. In numerous scientific papers devoted to the information era, it is mostly emphasized that not only the technological base and information and technological capabilities of a person, but also a person him/herself, his/her self-consciousness are changing. The world of a modern person can not be imagined without information technologies, which have a huge impact on all his or her existence, both biological and social. The subject of the discussions is only what these changes bring.

In the information society, the new characteristics of an individual are actualized, which represent a variety of role models and life styles. A request for a "modular person" is formed, a person capable of changing the types of activities, his or her own beliefs, the spheres of social system (organization, community, grouping). At the same time, the information society multiplies the intellectual abilities and creative potential of an individual $/ 11 /$.

The problems of personality in the information society are embodied in the postmodern discourse through the reflection by the representatives of this philosophical paradigm (first of all, by J. Baudrillard) of the diversity of modifications of human subjectivity in the electron-digital environment, the virtual transformation and simulation of an individual, the acquisition by him/her of his/her "virtual body" and actualization of the number of communicative threats connected with the substitution of reality with its simulation /12/.

Among the conceptual characteristics of the information society, experts distinguish the transformation of social roles and identity of an individual, change of the main subjects and objects of management, when the ideas and symbols took the place of material objects, as well as the formation of a new person - "an information person". In the context of these characteristics it is necessary to comprehen- 
sively analyze the impact of informatization on a person, taking into account physical, psychological and social factors of human existence. Only in this case, the new opportunities of the information society can be fully used for the development of a person. Without taking into account the specifics of these factors of human existence, informatization can lead to negative social consequences.

Today, there are many studies in various fields of knowledge devoted to the problems of personality that arise in the conditions of the information society $/ \mathbf{1 3} /, / \mathbf{1 4} /, / \mathbf{1 5} /$. Their analysis gives the grounds for highlighting, in particular, the following basic social problems of adaptation of a person to the changing conditions of the information society:

- the problem of linguistic communication, which forms the core of informatization;

- the problem of information security of an individual, which refers to the state of the security of the information environment of society, which ensures its formation and development in favor of citizens, organizations and the state. The problem of ensuring information security of an individual means his/her right to obtain objective information and suggests that the information received by a person from different sources does not impede the free formation and development of his or her personality.

Information processes have certain impacts on a person which have a manipulative character, namely /16/:

- $\quad$ targeted information pressure in order to change the outlook, political views and moral and psychological state of people;

- distribution of inaccurate, distorted, incomplete information;

- $\quad$ use of inadequate perceptions of reliable information by people. Information impacts are dangerous or useful not only by themselves, but by that fact that they control the powerful material-energy processes. The essence of the impact of information is precisely its ability to control material-energy processes, which parameters are much more higher than the information itself;

- computer crime, viruses. Attempts by creators of viruses, who, as a rule, are young people to realize themselves in the virus- creating can be due to a number of reasons: the wish to self-assert, to become known, and because of the lack of conscious life goals.

As we see, the existential rooting of a modern man into the informational and technical determinants of civilization development, undoubtfully, is becoming a topical problem today. Socio-cultural dimensions of the information society are also conditioned by the emergence of a special type of autonomy of an individual: a person can change his or her corporate connections without being firmly tied to them. A person may be capable to flexibly build relationships with other people, be engaged in various social communities and different cultural traditions. A world that is constantly changing overestimates the value of the past, forcing people to simultaneously join different cultural traditions, and adapt to dynamic socio-cultural and technological circumstances.

Modern technologies, getting included in the sphere of social relations, become an important factor in social transformations. In addition, recorded changes in the sphere of spiritual culture, are caused not by the conscious creative actions of a man, but by impersonal logic of technical development, processes of self-organization of an industrial environment. For example, information technologies, based on streamlining information and providing its accessibility, unify social practices, provide inclusion of people into the global information exchange. Through profound transformations of individual and mass consciousness, they become an instrument of psychological pressure, violent interference with the emotional and volitional sphere of a man. In today's information society, sublimated forms of aggression are rapidly spreading. Today, aggression and violence have gained a new look. Social aggression has become an inevitable and logical consequence of the transformational processes in society, which are accompanied by a rupture of economic ties, catastrophic socio-economic stratification of the population, a sharp decline in living standards, regional conflicts, and a crisis of morality. It became apparent that the creation of the global information field, in addition to 
Media, Culture and Public Relations, 10, 2019, 1, 30-41

accelerating mutual cultural exchange, leads to the destruction of traditional values $/ \mathbf{1 0} /$.

The development and expansion of the technical sphere stays less and less independent from the aspects of human activity. The constant growth of material and cultural needs stimulates the development of industry and the improvement of technology to increase the efficiency of material production. But at the same time, technological innovations shake both the traditional foundations of social life and the base of traditional culture. These technological changes substantially transform not only the environment of human existence, but also affect a person himself, the organization of all types of human activity, market relations between communities of people, the system of education and, finally, political and legal norms and laws.

\section{Difficulties and prospects of adap-} tation of a man to the conditions of the information society

All of the above suggests that today the problem of successful adaptation of a person in the modern information environment comes to the fore. The problem of adaptation of a man is inseparable from the question of its very essence, actual for the philosophers at all times. Domestic and foreign researchers have repeatedly turned to this issue. The information environment, becoming an increasingly important and integral part of the environment, brings to the person growing adaptive requirements. Humanity is constantly adapting to the natural and artificial environment. However, the life of a modern person is determined by special information and technological realities, new environmental and social circumstances. As L. Ovsiankina notes, the modern world as a system of complex and contradictory global socio-economic, political, spiritual, cultural and informational relationships actively leads humanity to the development of new values and ideological guidelines necessary for its survival today. In the era when the past authorities and stereotypes are destroyed, a lack of spirituality can become a serious threat to the further development of modern civilization /17/. Therefore, as never before, there is a demand for the ability of a person to accept the challenges of information civilization and be responsible for the own actions and their consequences.

In conditions of the development of computer networks, the creation of specific virtual communities, which is accompanied by a broad social and cultural differentiation is taking place. An important anthropological aspect is the problem of alienation, when the lack of direct communication and passive consumption of information form in a person the lack of thinking, inability to formulate volumetric meanings and cause difficulties in direct communication. But in general, "the formation of the information society has generated channels of transmission of socio-cultural norms and values" /10/, which is typical for the emergence of mass culture, manipulation with human consciousness. As a result, the cultural aspect of the "network" man is important and contributes to the emergence now of a new type of culture as the culture of society of the informatization era.

As to the question of the influence of the network reality of the information society on the moral world of a man, diametrically opposed points of view are expressed. Assessments range from purely negative, as a source of depravity and immorality, to inspirational belief in the ability to solve all social problems. The crisis of traditional forms of communication inevitably leads to a crisis of morality, since it forms the samples of proper ideal relationships between people. The network space provides an opportunity for language learning, facilitates knowing the world culture, facilitates participation in interactive conferences, scientific events. In other words, there is the choice before a person: to use the network as an entertainment, or through it, to get engaged in one's own education and spiritual development. And this choice will depend not on the availiability of the Internet, but on the education and social environment of a person. Consequently, the network reality is a place of the bright expression of a person's individual qualities.

It can be noted that in today's conditions, information and communication technologies have a significant impact on trans- 
formation of a person. Technological development creates new, different from the traditional conditions of human existence. Information technologies created conditions for the development of biotechnology, which can already change us, but not the nature of our actions /18/. According to modern Ukrainian researchers, awareness of the preconditions for creating human biotechnological perspectives, in which the ethics of science and technology plays a leading role, is one of the main issues of the anthropological polemics of our time $/ 19 /, / 20 /, / 21 /, / 22 /$.

Modern science and technology, which traditionally focuses on the transformation of the objective world, not only involves into the sphere of human activity fundamentally new types of objects, but also creates them. Such objects include a person as a special component. This is, in particular, about such complex systems as the objects of modern biotechnologies, social objects, systems of artificial intelligence, complex information systems, etc. When studying such objects, the search for truth is associated with the definition of possible directions for the transformation of such an object. Consequently, the space of the modern stage of scientific and technological development directly touches on humanistic values.

In identifying future anthropological changes, it is necessary to stress the ethical consequences of technological changes. As E. Fromm notes, a person reacts to changes in the external environment by changing oneself, and these psychological factors, in their turn, contribute to the further development of the economic and social process" /23/.

On this basis, a person faces a choice based on the awareness of both the negative effects of "immersion" into the space of the information society, and the constructive, positive opportunities caused by the benefits of such a society.

However, the integration of humanity and information technologies mostly leads to negative consequences. For example, the American futurologist E. Toffler cites D.Miller's reasoning about the human mental health, "The mechanism of human behavior breaks under the influence of information overload ... but now, without understanding its potential impact, we increase the speed of change in society. We press on people, forcing them to adapt to new rhythms of life ... we urge them to process information at a much faster rate. Therefore, we can not doubt that we will expose their consciousness to overexcitement" /24/.

Thus, the new network organizational form of the existence of a society contributes to the formation of a new "network person". Moreover, communications take a direct part in the formation and play a decisive role in the transformation of such a person. A "network person" is characterized with a number of differences, the first of which is the environment of interaction. A person lives in such a communicative space in which there are no boundaries, and the relationships are characterized by new features that arise on the basis of horizontal ties. The next important boundary of the "computer" person is the transformation of space and time, which also became the result of information modernization and development of communications. The third characteristic of the new "network" person is the loss of identity. The culture of "virtual reality" becomes the fundamental fourth boundary of the new "network" person. The fifth difference is gender changes. The main contradiction between the emerging network society and a man is the contradiction between the globalization of the world and the identity of a particular person, between the virtual space and the presence of small ethnic and cultural groups that claim to preservation of identity.

The life of a modern person is going on in the context of increasingly active interaction with technical devices. Earlier, they were like a continuation of human hands and contributed to increasing his or her physical potency. The emergence of the computer has sharply changed the situation: it plays the role of a co-worker, who, together with a person, performs complex intellectual work.

A man aspires to and potentially ready to live and work in a qualitatively new information environment, to adequately perceive its realities and, moreover, to successfully develop it. Thus, it changes not only the conditions 
of a person's life, but also it itself. However, these changes are controversial. This is due to many diverse factors, such as the need to allocate significant resources of society, the inevitable and often painful breakage of various structures (socio-economic, productiontechnological, cultural, informational, etc.). In addition, the difficulties of culturalpsychological adaptation of a man to nontraditional information tools and technologies are added. In short, this process can not be imagined as a purely positive phenomenon, without disadvantages, losses and undesirable consequences.

One of the most important moments to be taken into account in the first place is the possible negative impact of the latest information tools and technologies on the health of people, especially children and adolescents. In addition, now, in the era of a sharp increase in the role of computer technology, the problem of preserving the identity of a human person becomes of particular importance. This question is relevant not only in the context of theoretical understanding of the place of a man in modern society. The problem of preserving human self is also important in connection with the overwhelming need for new approaches to human upbringing. There is a fear that the computerization of the activity of a specialist who does not possess the fundamental culture, solving cognitive tasks, can turn a person into an appendage of a machine, deprive it of his/her ability to be engaged in creative activity.

Many researchers started speaking about the emergence of a man of the new culture, which demonstrates the dependence of the transformation of consciousness on the use of a completely new for human hands tool which is a button. Indeed, the user of a personal computer spends so much time with it and so quickly gets used to the mechanisms of the work that it can be affirmed that the button becomes a new cultural artifact.

In the world of global information flows, uncontrolled growth of information resources and unlimited access to them, a person faces the problem of processing information, choosing the necessary for his/her activities. And here the computer is not an assistant, it can only give out the search result, but the analysis of the information is the task to human thinking. And it is not always ready for this choice, and then there comes a decrease in perception and mental abilities, and often a psychological dependence on new information technologies /10/.

Under the influence of the information environment there are radical transformations in the human consciousness. Rational activity is realized on the basis of solving a complex task of development of thinking, the task of operating formal concepts and objects. In this regard, the development of computer technology generates new paradigms in scientific representations and, accordingly, changes in the habits and attitudes of people. New paradigms contribute to redefining a person's place in the information environment and, accordingly, form a new awareness of oneself and one's own rights and freedoms, in particular the information ones $/ \mathbf{2 6 /}$.

The problems of human ecology, associated with the rapid development of information technologies should be highlighted separately. As a result of the creation of the new environment (information) by a man, the situation occurs in which the human body responds to changes in the environment with the emergence of new occupational diseases, chronic stress of the adaptation systems. The listed problems that arise during the interaction of a man and the modern information environment, require further complex comprehension to find the best ways to solve them.

\section{Conclusions}

Thus, the information environment is a factor that requires a fundamentally new adaptation of a man. The specificity of the modern information environment leads to the correction of existing and the development of new natural and social mechanisms of human adaptation. Information technologies, having become the core of the modern civilization, change not only the quality and content of the life of modern humans, they threaten to transform the very way of their existence in the world. Information society inherent in the great freedom to choose the models of human behavior, 
Oleg Gennadievich Danilyan, Alexander Petrovich Dzeban, Yury Yurievich Kalinovsky, Svetlana Borisovna Zhdanenko, Eduard Anatolievich Kalnytskyi: PROBLEMS OF ADAPTATION OF A MAN TO THE CONDITIONS OF INFORMATION SOCIETY

Media, Culture and Public Relations, 10, 2019, 1, 30-41

mainly due to distance people from each other in the process of livelihoods. On conditions of the availability and relative ease and speed of information production, the status of producer and distributor of information loses its elitism, because it can be done by almost any individual. The information civilization, like the society of knowledge, seeks precisely to this.

Therefore, we emphasize that the information society really stands on the threshold of modern history, and the nature of the future civilization depends on how people can perceive and interpret it. Like any revolutionary process, the transition to the information society can have unpredictable consequences. The dangerous turn of events is extremely likely, it is worth imagining only the situation of monopolization of the planetary information system or its subordination to the selfish interests of certain groups. Therefore, the problems of the vectors of the development of the information society, the development of adequate to the objective reality methods and means of its life are the collective concern of all mankind.

Notes

/1/ Bures, V., Otcenaskova, T. (2018). Complexity of Information Society Achievement of Satisfactory Decision Making. Postmodern Openings, Vol. 9, Issue 2, 175-195.

/2/ Coeckelbergh, M. (2018). Techbology and the good society: A polemical essay on social ontology, political principles, and responsibility for technology. Technology in Society, Vol. 52, 4-9.

/3/ Ramos Grijalva, R.-D., Arévalo Tapia, M.-G. (2018). The prevalence of the knowledge society or the information society as structuring elements of the social system. Prisma Social, Issue 20, 333-346.

/4/ Schandl, H. (2017). Why do we need a sociology of society's natural relations to inform sustainable development? Social Science and Sustainability, 9-22.

/5/ Bohdanova, N.H. (2017). Problema samorealizatsii liudyny u suchasnomu informatsiinomu suspilstvi. Hileia: naukovyi visnyk - Gilea: Scientific Bulletin, Vol. 126, 316-319.

/6/ Voronkova, V., Kyvliuk, O. (2017). Philosophical Reflection Smart-Society as a New Model of the Information Society and its Impact on the Education of the 21st Century. Future $\mathrm{Hu}$ - man Image-An International Journal for Philosophy, Psychology and Education, Issue 7, 154-162.

/7/ Drozdovska, O. (2018). Vzaiemodiia media, Internet i liudyny yak faktor vdoskonalennia informatsiinoho suspilstva: sotsialnofilosofskyi analiz. Humanitarnyi visnyk Zaporizkoi derzhavnoi inzhenernoi akademii - Humanitarian Bulletin Zaporizhzhya State Engineering Academy, Vol. 73, 41-61.

/8/ Mykhalchuk, A.O. (2018). Styli koduvannia ta yikh vplyv na intelekt liudyny $\mathrm{v}$ konteksti suchasnoho informatsiinoho suspilstva. Hileia: naukovyi visnyk - Gilea: Scientific Bulletin, Vol. 137, 207-211.

/9/ Tiurina, T.H. (2017). Bezdukhovnist yak chynnyk samoruinuvannia liudyny i suspilstva (u konteksti informatsiinoenerhetychnoi paradyhmy). Dukhovnist osobystosti: metodolohiia, teoriia i praktyka - Personality Spirituality: Methodology, Theory and Practice, Vol. 3, 287-299.

/10/ Suspilstvo, liudyna, pravo: dosvid filosofskopravovoho osmyslennia: O.H.Danylian (Ed.) et al (2018). Kharkiv: Pravo.

/11/ Maklyuen, G.M. (2005). Galaktika Gutenberga. Stanovlenie cheloveka pechatayuschego. Moskva: Akademicheskiy Proekt.

/12/ Bodriyyar, Zh. (2000). V teni molchalivogo bolshinstva, ili Konets sotsialnogo. Ekaterinburg: Izd-vo Uralskogo Universiteta.

/13/ Dzoban, O.P. (2014). Homo informaticus: do problemy osmyslennia sutnosti. Visnyk Natsionalnoho universytetu «Iurydychna akademiia Ukrainy imeni Yaroslava Mudroho». Seriia : Filosofiia, filosofiia prava, politolohiia, sotsiolohiiaBulletin of the National University "Legal Academy of Ukraine named after Yaroslav the Wise". Series: Philosophy, Philosophy of Law, Political Science, Sociology, Vol. 1 (20), 13-21.

/14/ Kondrusieva, V.M. (2014). Informatsiine suspilstvo u konteksti suchasnoi tsyvilizatsiinoi sytuatsii (sotsialno-antropolohichnyi aspekt). Odesa: Bondarenko M.O.

115/ Harlamov, S.Yu. (2009). Filosofskoantropologicheskie modeli cheloveka V kontseptsiyah informatsionnogo obschestva. Candidate's thesis. Belgorod.

/16/ Dzoban, O.P. (2013). Filosofiia informatsiinoho prava: svitohliadni i zahalnoteoretychni zasady. Kharkiv: Maidan.

/17/ Ovsiankina, L.A. (2012). Filosofskyi analiz roli dukhovnykh tsinnostei u rozvytku suchasnoi tsyvilizatsii. Hileia: naukovyi visnyk - Gilea: Scientific Bulletin, Vol. 64 (№ 9), 224-229 .

18/ Baranov, P.P., Mamychev, A.Yu., Mordovtsev, A.Yu, Danilyan, O.G., Dzeban, A.P. 
Oleg Gennadievich Danilyan, Alexander Petrovich Dzeban, Yury Yurievich Kalinovsky, Svetlana Borisovna Zhdanenko, Eduard Anatolievich Kalnytskyi: PROBLEMS OF ADAPTATION OF A MAN TO THE CONDITIONS OF INFORMATION

SOCIETY

Media, Culture and Public Relations, 10, 2019, 1, 30-41

(2018). Doctrinal-Legal and Ethical Problems of Developing and Applying Robotic Technologies and Artificial Intelligence Systems (Using Autonomous Unmanned Underwater Vehicles). National Academy of Managerial Staff of Culture and Arts Herald, Vol. 2 (3), 465472 .

/19/ Kachak, N. (2013). Filosofske osmyslennia buttia liudyny kriz pryzmu suchasnykh biotekhnolohii. Visnyk Prykarpatskoho universytetu. Filosofski i psykholohichni nauky - Bulletin of the Precarpathian University. Philosophical and psychological sciences, Vol. 17, 123-129.

/20/ Nikolaienko, N.V. (2012). Aksiolohichnyi vymir novitnikh biotekhnolohichnykh praktyk. Visnyk Natsionalnoho tekhnichnoho universytetu Ukrainy «Kyivskyi politekhnichnyi instytut». Filosofiia. Psykholohiia. Pedahohika - Bulletin of the National Technical University of Ukraine "Kyiv Polytechnic Institute". Philosophy. Psychology. Pedagogy, Vol 3, 42-48.

/21/ Slobodian, O.M. (2011). Etyko-pravovi problemy zastosuvannia biotekhnolohii. Univer- sytetski naukovi zapysky - University scientific notes, Vol. 1, 56-63.

/22/ Tereshkun, O. (2011). Suchasni biotekhnolohii ta identychnist indyvida. Naukovi zapysky Natsionalnoho universytetu "Ostrozka akademiia». Seriia: Filosofiia - Scientific notes of the National University "Ostroh Academy". Series: Philosophy, Vol. 8, 230-242.

/23/ Fromm, E. (1990). Begstvo ot svobodyi. Moskva: Progress.

/24/ Toffler, E. (2001). Shok buduschego. Moskva: AST.

/25/ Loginov, V.A. (2002). Internet: vse li tak prosto? O psihologicheskih problemah ispolzovaniya seti Internet v obrazovanii. Gumanitarni nauki - Humanities, Vol. 2, 154-156.

/26/ Danilyan, O.G., Dzeban, A.P., Kalinovsky, Y.Y., Kalnytskyi, E.A., Zhdanenko, S.B. (2018). Personal information rights and freedoms within the modern society. Informatologia, Vol. 51 (1-2), 24-33. 


\title{
PROBLEMI PRILAGODBE ČOVJEKA UVJETIMA INFORMA- CIJSKOG DRUŠTVA
}

\section{Oleg Gennadievich Danilyan, Aleksandar Petrovich Dzeban, Yury Yurievich Kalinovsky, Svetlana Borisovna Zhdanenko, Eduard Ana- tolievich Kalnytskyi \\ Nacionalno pravno sveučilište Yaroslav Mudryi, Harkov, Ukrajina}

\begin{abstract}
Sažetak
Autori utvrđuju glavna obilježja prilagodbe čovjeka uvjetima informacijskog društva. Primijenjen je čitav kompleks filozofskih, opće-znanstvenih i specifičnih metoda inherentnih filozofskim istraživanjima u njihovoj povezanosti i komplementarnosti. Metodologija istraživanja temelji se na načelima sistemske i strukturno-funkcionalne analize. Kao rezultat istraživanja ustanovljeno je da čovjek kao najviša društvena vrijednost akumulira i fiksira u glavnim oblicima svoga života međupovezanost materijalnog i duhovnog, što se $u$ integralnom obliku odražava u životu kao objektivnoj stvarnosti, gdje se otkrivaju interesi, moralne vrijednosti, ideali, njegova kultura, vjerske sklonosti i subjektivno razumijevanje smisla života. Širenje informacijske tehnologije popraćeno je virtualizacijom svih sfera ljudskog života. Glavni društveni problemi prilagodbe ljudi promjenjivim uvjetima informacijskog društva koje se predlažu su: problem lingvističke komunikacije, koja čini jezgru informatizacije, te problem informacijske sigurnosti pojedinca. Utvrđeno je da nove paradigme oblikuju novu percepciju osobe o svom mjestu u odnosu na informacijsko okruženje i, shodno tome, novu svijest o sebi i vlastitim pravima i slobodama. Specifičnost suvremenog informacijskog okruženja dovodi do korekcije postojećih prirodnih i društvenih mehanizama prilagodbe osobe i razvoja novih. Informacijske tehnologije, postajući jezgra moderne civilizacije, mijenjaju ne samo kvalitetu i sadržaj života modernog čovjeka, nego prijete transformirati sam način njegovog / njezinog postojanja u svijetu. Prijelaz na informacijsko društvo može imati nepredvidive posljedice. Stoga su problemi formiranja informacijskog društva, razvoja adekvatnih metoda objektivne stvarnosti i sredstava njegova života kolektivna briga cijelog čovječanstva.
\end{abstract}

Ključne riječi

informacijsko društvo, adaptacija, virtualizacija, informacijska tehnologija 